Article

\title{
Small Boreal Lake Ecosystem Evolution under the Influence of Natural and Anthropogenic Factors: Results of Multidisciplinary Long-Term Study
}

\author{
Liudmila Shirokova ${ }^{1,2, *}$, Taissia Vorobyeva ${ }^{1}$, Svetlana Zabelina ${ }^{1}$, Sergey Klimov ${ }^{1}$, \\ Olga Moreva ${ }^{1}$, Artem Chupakov ${ }^{1}$, Natalia Makhnovitch ${ }^{3}$, Vladimir Gogolitsyn ${ }^{3}$, Elena Sobko ${ }^{1}$, \\ Natalia Shorina ${ }^{1,4}$, Natalia Kokryatskaya ${ }^{1}$, Anna Ershova ${ }^{1}$ and Oleg Pokrovsky ${ }^{1,2,5}$ \\ 1 Institute of Environmental Problems of the North, Federal Center for Integrated Arctic Research, \\ Russian Academy of Sciences, Severnoy Dviny Embankment, 23, Arkhangelsk 163000, Russia; \\ vtais345@gmail.com (T.V.); svetzabelina@gmail.com (S.Z.); kliopa@atnet.ru (S.K.); \\ mapycr1@yandex.ru (O.M.); artem.chupakov@gmail.com (A.C.); elfisina@yandex.ru (E.S.); \\ nvshorina@yandex.ru (N.S.); nkokr@ya.ru (N.K.); nurka90@bk.ru (A.E.); oleg@get.obs-mip.fr (O.P.) \\ 2 Georesources and Environnement Toulouse GET UMR 5563 CNRS, Université Paul Sabatier, 14 Avenue \\ Edouard Belin, Toulouse 31400, France \\ 3 The North-Western Branch of the P.P. Shirshov Institute of Oceanology of the Russian Academy of Sciences, \\ 112/3, Northern Dvina Embankment, Arkhangelsk 163061, Russia; nmakhnovich@yandex.ru (N.M.); \\ valgog@yandex.ru (V.G.) \\ 4 Lomonosov Northern (Arctic) Federal University, 17, Northern Dvina Embankment, \\ Arkhangelsk 163002, Russia \\ 5 BIO-GEO-CLIM Laboratory, Tomsk State University, Prospekt Lenina 36, Tomsk 634050, Russia \\ * Correspondence: LShirocova@yandex.ru; Tel.: +7-905-873-2982
}

Academic Editors: Erik Jeppesen and Martin Søndergaard

Received: 1 June 2016; Accepted: 19 July 2016; Published: 26 July 2016

\begin{abstract}
Small aquatic ecosystems of the boreal zone are known to be most sensitive indicators of on-going environmental change as well as local anthropogenic pressure, while being highly vulnerable to external impacts. Compared to rather detailed knowledge of the evolution of large and small lakes in Scandinavia and Canada, and large lakes in Eurasia, highly abundant small boreal lakes of northwest Russia have received very little attention, although they may become important centers of attraction of growing rural population in the near future. Here we present the results of a multidisciplinary, multi-annual study of a small boreal humic lake of NW Russia. A shallow (3 m) and a deep $(16 \mathrm{~m})$ site of this lake were regularly sampled for a range of chemical and biological parameters. Average multi-daily, summer-time values of the epilimnion (upper oxygenated) layer of the lake provided indications of possible trends in temperature, nutrients, and bacterio-plankton concentration that revealed the local pollution impact in the shallow zone and overall environmental trend in the deep sampling point of the lake. Organic phosphorus, nitrate, and lead were found to be most efficient tracers of local anthropogenic pollution, especially visible in the surface layer of the shallow site of the lake. Cycling of trace elements between the epilimnion and hypolimnion is tightly linked to dissolved organic matter speciation and size fractionation due to the dominance of organic and organo-ferric colloids. The capacity of lake self-purification depends on the ratio of primary productivity to mineralization of organic matter. This ratio remained $>1$ both during winter and summer periods, which suggests a high potential of lake recovery from the input of allochthonous dissolved organic matter and local anthropogenic pollution.
\end{abstract}

Keywords: boreal; multidisciplinary long-term study; small lake 


\section{Introduction}

A growing interest in the carbon cycle of subarctic and arctic regions is caused primarily by climate change, which is most pronounced in high latitudes, where it leads to increased emissions of greenhouse gases carbon dioxide $\left(\mathrm{CO}_{2}\right)$ and methane $\left(\mathrm{CH}_{4}\right)$ from the water surfaces, which potentially enhances the effect of global warming. In this regard, over the past decades, a priority for basic research has led to a complex ecosystem study of the northern lakes. However, study of the status and the change of lake ecosystems in the context of climate change requires consideration of the influence of anthropogenic factors.

Annual trends in the physical, chemical, and biological parameters of boreal lakes became a topic of high interest within the context of climate warming and the response of biogeochemistry of carbon in high-latitude aquatic ecosystems, with increasing ground and water temperatures being among the key issues of the prediction of ecosystem evolution under on-going environmental changes [1-4]. This prediction, however, is significantly hampered by the lack of knowledge of aquatic ecosystem response to one of the main consequences of climate warming - the rising of surface water temperatures. One of the most efficient traditional methods of assessing the effect of long-term environmental change is continuous monitoring of whole lake ecosystems, which includes a suite of parameters, from hydrochemical to fish population, routinely conducted in various boreal and temperate regions (see refs. [5] and [6] for a recent review).

In Russia, such long-term monitoring is known for large lakes [7], with almost no observations of small lakes. Yet, small lakes are likely to be the most sensitive indicators of on-going environmental changes, being at the same time highly vulnerable to both local anthropogenic pressure and global climate change. In this regard, small boreal humic lakes of European Russia deserve special attention. In the Arkhangelsk region (NW Russia), there are over 200,000 lakes. Most of them are located to the west of the Onega River, between the middle and upper reaches of the Onega River and the southwestern boundary of the area. This region is dominated by lakes having surface areas of $\leqslant 50 \mathrm{~km}^{2}$, conventionally classified as small lakes with moderate or significant anthropogenic impact. The global trends of water ecosystem evolution can be, however, strongly biased by local effluent discharge, such as from the dairy industry [8]. Thus, phosphate is widely recognized as a very efficient tracer of urban wastewater efflux to the environment [9].

Detailed study of organic carbon and trace metal speciation in the water column of the Svyatoe Lake-a representative humic stratified lake of the Russian boreal zone-allowed the creation of a comprehensive picture of organic and mineral colloids formation, biodegradation, and exchange between surface and deep waters and sediments. In particular, we demonstrated the impact of the anomalously hot summer in 2010 on the increase of low molecular weight (potentially bioavailable) forms of dissolved organic carbon (DOC) and metals, primarily linked to enhanced photo- and bio-degradation of large size allochthonous soil dissolved organic matter (DOM) coupled with production of phytoplankton exometabolites [10]. In addition, observations of the diel photosynthetic cycle of the shallow zone of this lake during the hot summer's cyanobacterial bloom revealed the existence of coupled DOC-Fe-Mn speciation cycle in the surface water layer linked to alternative photosynthetic activity and heterotrophic aerobic plankton respiration [11]. In contrast to rather detailed understanding of lake water hydrochemistry and mechanisms regulating the biogeochemical cycle of organic carbon during recent years, the evolution of the lake ecosystem over past decades remains poorly known.

This work presents an overview of results of multidisciplinary study of the Lake Svyatoe, conducted since 2001 to the present time. We demonstrate the synchronous behavior of macro- and micro-nutrients in the deep and shallow zones of the lake and assess the degree of local anthropogenic pollution versus global climate trends, as well as catastrophic weather events. We conclude on the necessity of complex, multidisciplinary studies of small humic lakes in the boreal zone, because these "model" lakes can serve as important proxies of on-going environmental changes in highly abundant aquatic ecosystems of poorly accessible regions of NW Russia. 


\section{Study Site Description, Sampling, Methods, and Analysis}

Lake Svyatoe is located in the Arkhangelsk region (northern Europe) within the watershed of the Onega River near the Rotkovetz Scientific Monitoring Station $\left(60^{\circ} 51^{\prime} \mathrm{N} ; 39^{\circ} 32^{\prime}\right.$ E, Figure 1). The watershed's lithology is represented by glacial moraine (products of granite-gneisses erosion) and carbonate rocks. The lake has an overall surface area of $2.11 \mathrm{~km}^{2}$, its volume is $0.00749 \mathrm{~km}^{3}$, the maximum depth is $16 \mathrm{~m}$, and the average depth is $3.6 \mathrm{~m}$. There are several inlets to this lake and one outlet river, the Svyataya. The lake is strongly influenced by Dissolved Organic Matter (DOM) delivered from adjacent bogs which contain significant peat deposits. The lake exhibits a deep zone in its southern (relatively pristine) part, with minimal inlets having anthropogenic influence. Little human activity has been present near this southern part of the lake over the past 50 years, so the studied part of the lake can be considered almost pristine, similar to other lakes in the region [12]. In contrast, the northern-most bay (Maslozavod) is subjected to significant anthropogenic pollution from both local industry (milk and butter factory) and local inhabitants of approximately 30 houses, since there is no sewage system in the Rotkovetz village.

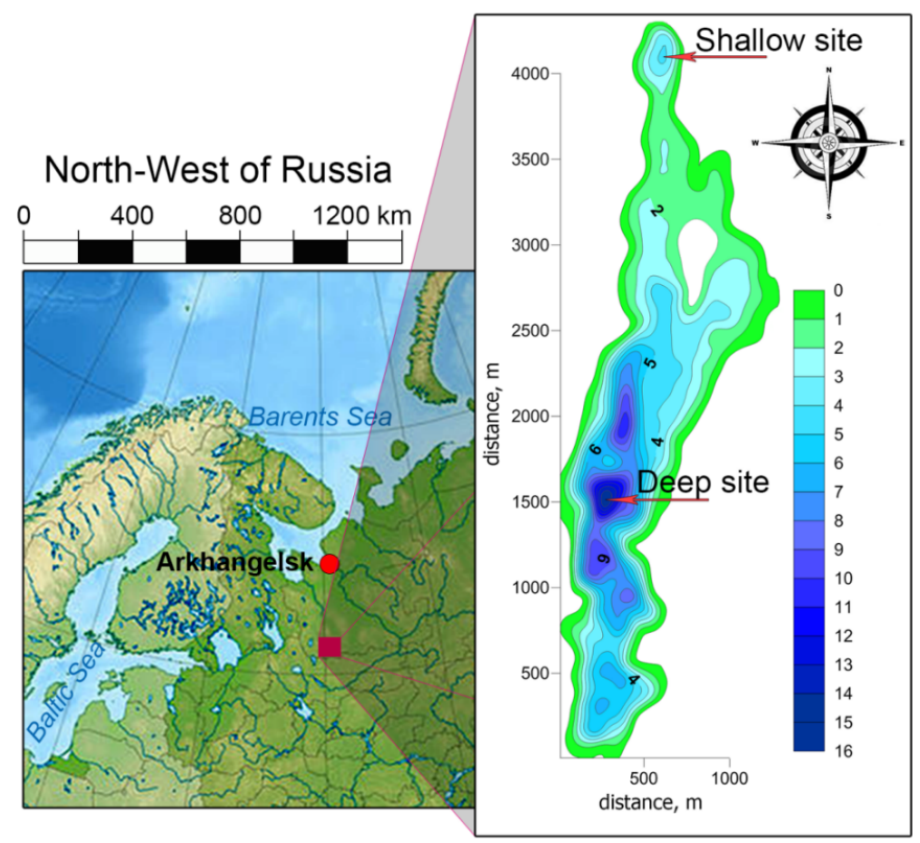

Figure 1. Schematic map of the studied area and batimetric map of Lake Svyatoe. Two sampled sites, the shallow (anthropogenically-impacted) and the deep (pristine) are marked by arrows.

The mean summer air temperature and precipitation of the region from 2001 to 2015 are illustrated in Figure 2A. Similar to other boreal and subarctic lakes, the lake exhibits two main periods of pronounced stratification (November to April and June to September) and two periods of lake overturn (October and May). The typical ice thickness at the end of winter, based on our 2 year period of observation, is $50 \pm 10 \mathrm{~cm}$. Maximal winter stratification is in March, and the highest water temperature typically occurs in July. The length of the ice-covered period of the lakes is between 195 and 201 days; the average freeze over date is 25-30th October and the average ice out date is 12-14th May [12]. Mean seasonal water temperatures over the full period of observations on the deepest stratified station of the lake are illustrated in Figure 2B,C.

The water samples were taken using a PVC boat in the summer time and from ice cover during the winter time from the two selected stations of the lake (Figure 1) using a pre-cleaned polycarbonate horizontal water sampler (Aquatic Research Instruments Inc., Hope, ID, USA); they were immediately filtered through sterile, single use Minisart ${ }^{\circledR}$ filter units (acetate cellulose filter, Sartorius ${ }^{\circledR}$, Göttingen, Germany) with a pore size of $0.45 \mu \mathrm{m}$. 
Filtration was performed directly on the boat in summer or on the ice in winter. Dissolved $\mathrm{O}_{2}$ level and temperature were measured in situ using the Oxi 197i oximeter (WTW ${ }^{\circledR}$, Weilheim, Germany) with a Cellox 325 submersible sensor $\left(\mathrm{WTW}^{\circledR}\right.$, Weilheim, Germany; $\pm 0.5 \%$ and $\pm 0.2^{\circ} \mathrm{C}$ uncertainty). The Winkler titration method was also used for $\mathrm{O}_{2}$ determination. The conductivity was measured on-site using a Hanna HI991300 conductivity meter (Hanna®Instruments, Inc., Ann-Arbor, MI, USA).
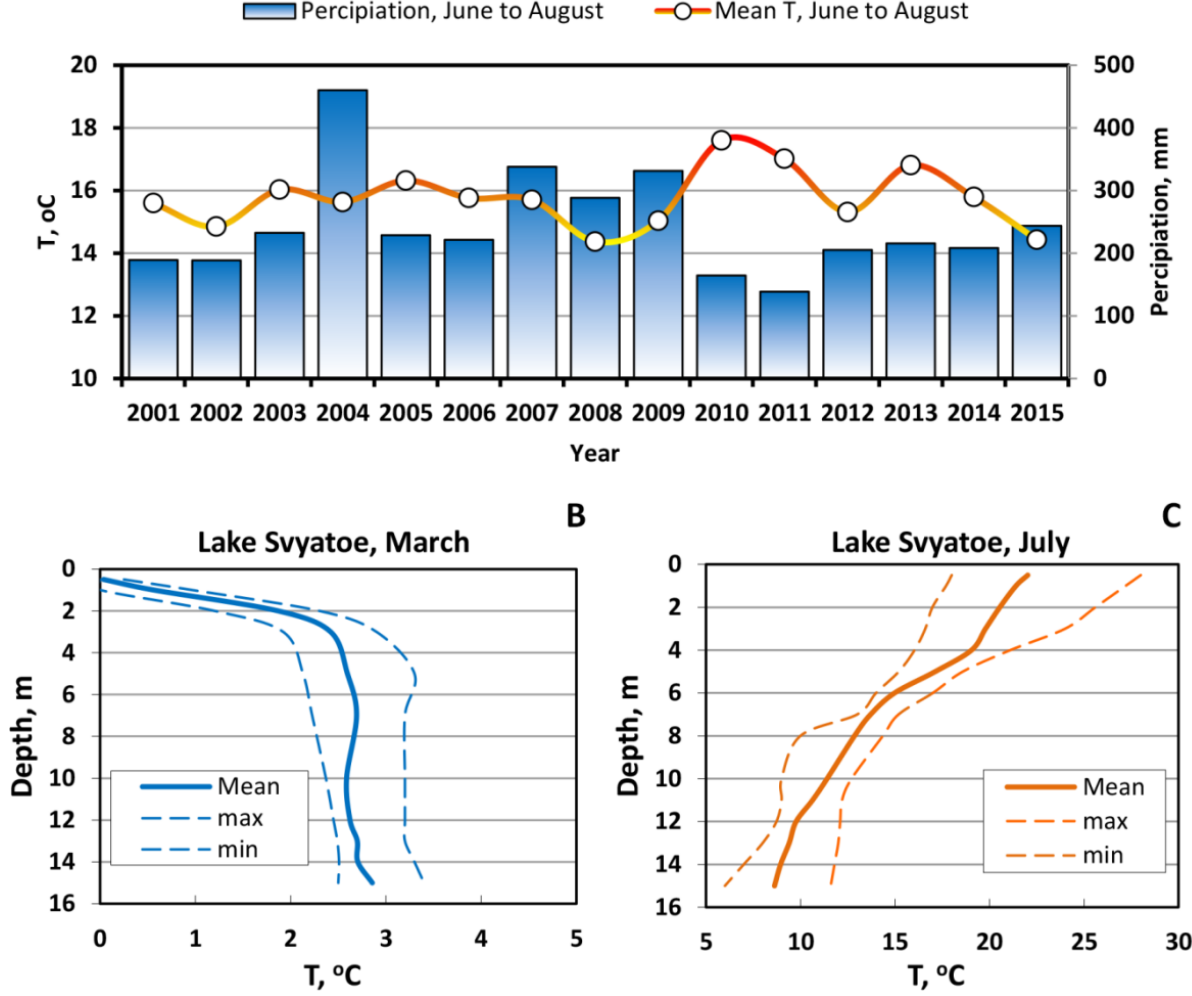

B

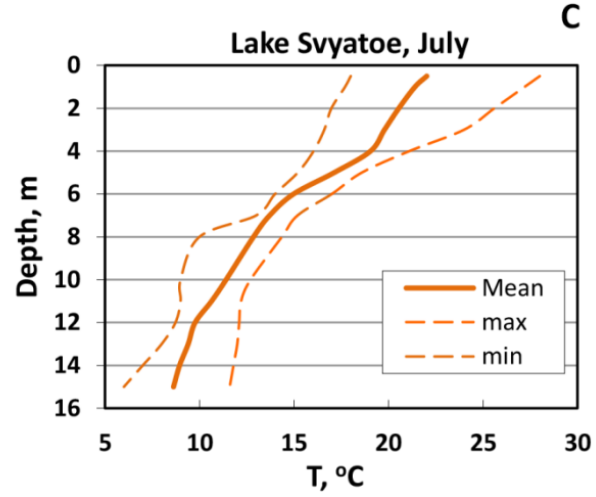

Figure 2. (A) Mean air summer temperatures and cumulative summer precipitation; water temperature in the Lake Svyatoe in (B) March and (C) July.

$\mathrm{pH}$ was measured in the field using a combined electrode calibrated against NIST (National Institute of Standards and Technology, Gaithersburg, MD, USA) buffer solutions ( $\mathrm{pH}=4.00$ and 6.86 at $25^{\circ} \mathrm{C}$ ). The accuracy of $\mathrm{pH}$ measurements was $\pm 0.02 \mathrm{pH}$ units. Filtered water samples for nutrient analyses were frozen $\left(-20^{\circ} \mathrm{C}\right)$ within 1 to $3 \mathrm{~h}$ after collection and analyzed within 1 week after sampling.

DOC and dissolved inorganic carbon (DIC) concentrations were measured using methods routinely used in the Geosciences and Environment Toulouse (GET) laboratory to analyze boreal water samples [10,12]. The nutrient determinations were based on colorimetric assays [13,14]. Total dissolved organic nitrogen (DON) was measured from the difference between the total dissolved nitrogen (persulfate oxidation) and the total dissolved inorganic nitrogen (DIN, or the sum of $\mathrm{NH}_{4}{ }^{+}$, $\mathrm{NO}_{2}{ }^{-}$, and $\mathrm{NO}_{3}{ }^{-}$). Uncertainties of DON and DIN analyses were between $10 \%$ and $20 \%$, and detection limits were between 10 and $50 \mu \mathrm{g} / \mathrm{L}$.

Major and trace elements, including Fe, were measured by Inductively Coupled Plasma Mass Spectrometry ICP-MS (7500 ce, Agilent Technologies, Santa Clara, CA, USA) without pre-concentration, an uncertainty of $5 \%$, and a detection limit of $0.02 \mathrm{ppb}$. Indium and rhenium were used as internal standards. The international geostandards SLRS-4 and SLRS-5 (Riverine Water Reference Material for Trace Metals certified by the National Research Council of Canada) were used to check the validity and reproducibility of each analysis (see refs. [10-12] for analytical details). There was good agreement between our replicated measurements of SLRS- 5 and the certified values (relative difference $<15 \%$ ). 
The biological availability of trace metal is known to be fully controlled by their speciation in aqueous solution. For example, permeation of free ions through the biological membrane is determined by ion transport channels having approx. 600 Da molecular size. Conventional filtration through a $0.45 \mu \mathrm{m}$ membrane cannot, therefore, account for the bioavailability of metals, and thus a fine size separation procedure via ultrafiltration/dialysis is necessary. In order to better characterize trace element speciation in the studied lake, we performed in situ dialysis over the full depth of the water column. These dialysis experiments were performed using 20 to $50 \mathrm{~mL}$ pre-cleaned dialysis bags placed at various depths during the different seasons. The duration of the dialysis procedure was between 72 and $96 \mathrm{~h}$, following kinetic experiments of dialysis equilibrium attainment for DOC, Si, and trace metals $[10,12]$. For dialysis experiments, EDTA-cleaned trace-metal pure SpectraPor $7^{\circledR}$ dialysis membranes made of regenerated cellulose with pore sizes of $1 \mathrm{kDa}$ were thoroughly washed in $0.1 \mathrm{M}$ double-distilled $\mathrm{HNO}_{3}$ and ultrapure water, and then filled with ultrapure MilliQ deionized water and placed into the lake at the desired depth. The interior compartment of the dialysis bag was retrieved after 3-4 days of exposure and analyzed for organic carbon and trace metals.

Samples for microbiological analyses were collected in sterile $250-\mathrm{mL}$ flacons and stored for less than $2 \mathrm{~h}$ in a portable cooler at $5^{\circ} \mathrm{C}$. Active bacteria number count (Colony forming units, $\mathrm{CFU} / \mathrm{mL}$ ) was done using Petri dishes inoculation ( 0.1 to $1.0 \mathrm{~mL}$ of lake water in three replicates) performed in a specially organized microbiological field laboratory (i.e., refs. [15-17]). All manipulations were performed in the vicinity of open flame on thoroughly alcohol- and detergent-treated and UV-sterilized microbiological table. Samples were inoculated on Nutrient Agar $(5 \mathrm{~g} / \mathrm{L}$ beef extract, $5 \mathrm{~g} / \mathrm{L}$ gelatine peptone, $15 \mathrm{~g} / \mathrm{L}$ bacteriological agar, $\mathrm{pH}=6.8 \pm 0.2$ at $25^{\circ} \mathrm{C}$ ) to determine the total number of heterotrophic bacteria. Difco ${ }^{\mathrm{TM}}$ agar (granulated powder) inoculation was used to assess the number of oligotrophic bacteria. Inoculation of blanks was routinely performed to assure the absence of contamination from external environments. Two duplicates of different volumes of lake water (normally 0.5, 1, $5 \mathrm{~mL}$ ) were inoculated on three types of agar nutrient media (nutrient Bacto agar, 1:10 diluted nutrient agar, and Difco nutrient-poor agar, for enumeration of eutrophic (E), facultatively oligotrophic (FO) and oligotrophic (O) bacteria, respectively). The number of colony-forming units (CFU) was evaluated by visual counting of colonies on the agar plate after 5, 10, and 30 days of incubation at $25^{\circ} \mathrm{C}$ in the dark for $\mathrm{E}, \mathrm{FO}$, and O-type bacteria, respectively.

In situ measurement of primary production and mineralization were performed via incubation of bottles with oxygen detection, either by the WTW oxymeter with dissolved oxygen (DO) polarographic sonde or by Winkler titration method. On each selected horizon, two transparent polycarbonate and two dark 0.5-L bottles were filled by filtered and non-filtered lake water and closed without bubbles. Exposure time varied from 24 to $72 \mathrm{~h}$. The oxygen analyses were performed in duplicate with an uncertainty of $2 \%$, a resolution of $0.1 \mathrm{mg} / \mathrm{L}$, and a detection limit of $0.2 \mathrm{mg} / \mathrm{L}$.

The chlorophyll $a$ was measured by spectrophotometry at six different wavelengths after extraction from $0.45 \mu \mathrm{m}$ filter using $90 \%$ acetone. For this, from 1 to $1.5 \mathrm{~L}$ of the lake water was processed. Typical analytical uncertainty of $\mathrm{Chl} a$ determination is $\pm 10 \%$ in the concentration range 0.1 to $10 \mu \mathrm{g} / \mathrm{L}$. For phytoplankton analyses, the lake water samples were stored in the refrigerator, concentrated by sedimentation, and counted in a Najotte chamber of $0.05 \mathrm{~mL}$ volume [18,19]. The biomass was determined as algal volume for each lake and converted to wet weight assuming a density of $1 \mathrm{~g} \cdot \mathrm{cm}^{-3}$ after approximating the geometry of the cell [20]. The microscopes AxioLab A1 and Axiovert CFL-40 (Carl Zeiss, GmbH, Oberkochen, Germany) were used to assess the cell number and morphology. The phytoplankton diversity was evaluated using the Shannon-Weaver's index $(H)$ and Pielou's index based on the biomass [21]. The saprobity state of the water bodies was evaluated using the modified indices of Pantle and Bukk [22,23]. Ichthyological material for the study of fish population in Lake Svyatoe was conducted in 2004 to 2006. Sampling was carried out by net with mesh size of 18 to $60 \mathrm{~mm}$.

The lake water components were analyzed using best fit functions based on the least squares method, Pearson correlation, and one way ANOVA with STATISTICA version 10 (StatSoft Inc., Tulsa, 
OK, USA). The regressions of concentration versus year of observation were calculated using mean average of several surface (oxygenated) horizons, provided that no trend of concentration with depth was observed. For constructing the general annual trends, we mainly used the weighted least squares regressions. The statistical test was aimed to assess the difference in element concentration between two sampling sites for the whole period of observation, from 2007 to 2010 during summer and winter periods. It included the Mann-Whitney U Test and allowed the estimation of the difference between two independent sets of data (shallow and deep site) based on one given parameter (nutrient or metal concentration), at the significance level of $p<0.1$.

\section{Results and Discussion}

\subsection{Long-Term Evolution of Lake Ecosystem}

A general compilation of all measured parameters in Lake Svyatoe between 2001 and 2014 is given in Table 1 . It can be seen from this table that the majority of measured parameters were monitored between 2003 and 2010. Bacterial population was assessed between 2001 and 2010. There were occasional measurements of $\mathrm{N}_{\text {total, }} \mathrm{Chl} a$, phyto and zooplankton and fish population. All measurements were performed during 1-3 days of sampling in July and in March, corresponding to periods of the most pronounced stratification. Despite significant discontinuity in documenting main hydrochemical and ecological parameters of the water column, today this is probably the only small boreal humic lake of NW Russia having such a long record of environmental parameters.

Table 1. Compilation of measured parameters of the Svyatoe Lake water column between 2001 and 2014. The sampling periods of most years are March and July/August. EB, FOB, OB and TB stand for eutrophic, facultative oligotrophic, oligotrophic and total bacterial number. TE represents approx. 40 trace elements routinely measured by ICP-MS, including major cations. PP and BD signifies primary production and bio-degradation intensity, respectively. DOC and DIC refer to dissolved organic and dissolved inorganic carbon, respectively. TDS signifies total dissolved solid and $\mathrm{BOD}_{5}$ represents 5-days Biochemical oxygen demand.

\begin{tabular}{|c|c|c|c|c|c|c|c|c|c|c|c|c|}
\hline \multirow{2}{*}{ Parameter } & \multicolumn{12}{|c|}{ Year } \\
\hline & 2001 & 2002 & 2003 & 2004 & 2005 & 2006 & 2007 & 2008 & 2009 & 2010 & 2013 & 2014 \\
\hline $\mathrm{T}$ & + & + & + & + & + & + & + & + & + & + & + & + \\
\hline $\mathrm{pH}$ & - & + & + & + & + & + & + & + & + & + & + & + \\
\hline TDS & - & + & + & + & + & + & + & + & + & + & + & + \\
\hline $\mathrm{BOD}_{5}$ & - & - & + & + & + & + & - & - & - & - & - & - \\
\hline $\mathrm{O}_{2}$ & - & - & + & + & + & + & + & + & + & + & + & + \\
\hline P total & - & - & - & - & + & + & + & + & + & + & - & - \\
\hline P organic & - & - & - & - & - & - & + & + & + & + & - & - \\
\hline $\mathrm{PO}_{4}^{3-}$ & - & - & + & + & + & + & + & + & + & + & - & - \\
\hline $\mathrm{N}-\mathrm{NO}_{3}$ & - & - & - & - & - & - & + & + & + & + & - & - \\
\hline $\mathrm{N}-\mathrm{NO}_{2}$ & - & - & + & + & + & + & + & + & + & + & - & - \\
\hline $\mathrm{N}$ total & - & - & - & - & - & - & - & + & + & + & - & - \\
\hline $\mathrm{N}$ organic & - & - & - & - & - & - & + & + & + & + & - & - \\
\hline $\mathrm{N}-\mathrm{NH}_{3}$ & - & - & - & - & - & - & + & + & + & + & - & - \\
\hline $\mathrm{SO}_{4}^{2-}$ & - & - & - & - & - & - & + & + & + & + & - & + \\
\hline $\mathrm{H}_{2} \mathrm{~S}, \mathrm{~S}^{2-}$ & - & - & - & - & + & + & + & + & + & + & + & + \\
\hline $\mathrm{Si}$ & - & - & + & + & + & + & + & + & + & + & - & - \\
\hline $\mathrm{Fe}, \mathrm{Mn}, \mathrm{TE}$ & - & - & - & - & - & - & + & + & + & + & - & - \\
\hline $\mathrm{Cl}^{-}$ & - & - & - & - & - & - & + & + & + & + & - & + \\
\hline DOC & - & - & - & - & - & - & + & + & + & + & - & + \\
\hline DIC & - & - & - & - & - & - & + & + & + & + & - & + \\
\hline EB & + & + & + & + & + & + & + & + & + & + & - & - \\
\hline FOB & - & + & + & + & + & + & + & + & + & + & - & - \\
\hline $\mathrm{OB}$ & - & - & - & - & + & + & + & + & + & + & - & - \\
\hline TB & + & + & + & + & + & - & - & - & - & - & - & - \\
\hline Chl $a$ & - & - & - & - & - & - & - & + & + & - & - & - \\
\hline
\end{tabular}


Table 1. Cont.

\begin{tabular}{ccccccccccccc}
\hline \multirow{2}{*}{ Parameter } & \multicolumn{110}{c}{ Year } \\
\cline { 2 - 12 } & 2001 & 2002 & 2003 & 2004 & 2005 & 2006 & 2007 & 2008 & 2009 & 2010 & 2013 & 2014 \\
\hline Phytoplankton & - & - & - & - & + & - & + & - & - & - & - & - \\
Zooplankton & - & - & + & + & + & - & + & - & + & + & - & - \\
PP and BD & + & + & + & + & + & + & + & + & + & + & - & - \\
Fish & - & - & - & + & + & + & - & - & - & - & - & - \\
\hline
\end{tabular}

Examples of the evolution of $T, \mathrm{pH}$, and some nutrients in the epilimnion of the pristine (deep) point and the human-affected (shallow) point of the lakes are shown in Figure 3A-D. For the calculation of the mean seasonal value of each year, the average of $0-5 \mathrm{~m}$ depth at the deepest station and surface $(0-2.5 \mathrm{~m})$ depth of the shallow station were used. Such a choice of the epilimnion parameters was determined by two reasons. First, we aimed to assess the response of the surface-presumably the most sensitive horizon - to possible environmental changes. Second, it allowed us to avoid the influence of anaerobic processes, including the accumulation of nutrients and redox-sensitive elements in the deeper, hypolimnetic horizon.

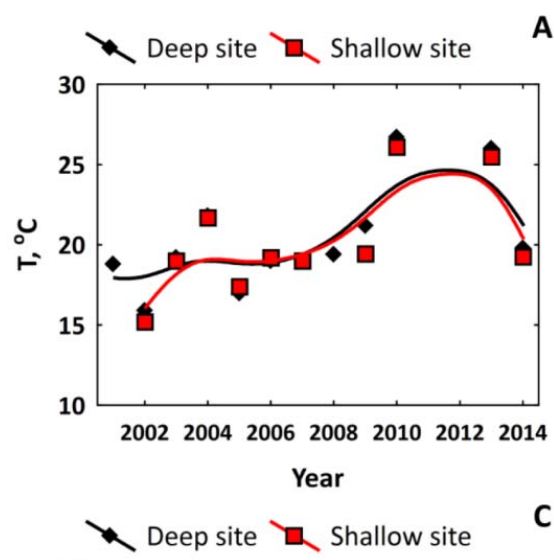

A
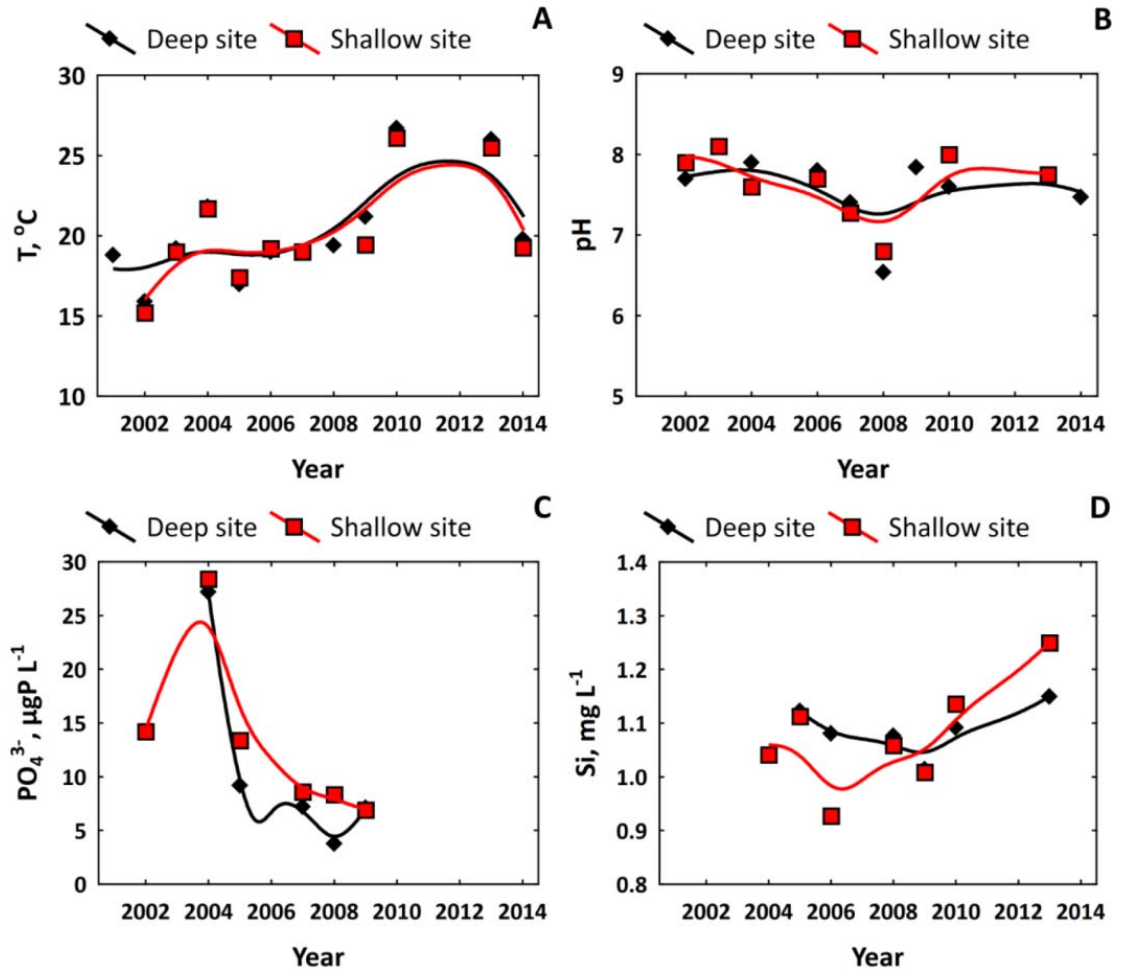

Figure 3. Evolution of (A) temperature; (B) $\mathrm{pH}$; (C) phosphate; and (D) silica in the epilimnion of Lake Svyatoe. The values are averaged over the oxic layer in deep (black diamonds) and shallow (open squares) sampling sites of the lake.

The most important result is that the multi-annual trends are not clearly pronounced and the main chemical parameters of the water column are not correlated $(R<0.5$ at $p=0.05)$ with mean monthly air temperature or atmospheric precipitation during the summer period.

\subsection{Nutrient Regime in Pristine and Anthropogenically-Affected Zones of the Lake}

The nutrient regime reflected in the concentration of organic and mineral phosphorus, nitrate, ammonia, organic nitrogen, silica, and heavy metals was quantitatively compared between the pristine (deep) zone of the lake and the anthropogenicaly-affected shallow sampling point, based on field 
campaigns in March and July of 2007, 2008, 2009 and 2010. Both the epilimnion and bottom horizon concentrations of $\mathrm{P}$ and $\mathrm{N}$ were significantly $(p<0.1)$ higher in the shallow point compared to the deep sampling point. A compilation of results, including the ratio of element concentration and statistical parameters of the significance of criteria, is given in Table 2. The use of the Mann-Whitney U Test allowed the estimation of the difference between the surface epilimnitic layer of the shallow and deep sites of the lake based on nutrient or metal concentration at the significance level of $p<0.1$. It can be seen from this table that significant $(p<0.1)$ enrichment of the shallow anthropogenically-affected site of the lake was mostly pronounced in March 2008 for Co and Zn, in March 2009 for phosphate and nitrate, in July 2009 for organic P, Cu, and Pb. In August 2010 (an anomalously hot summer [10]), the enrichment of the shallow site is significant for As and very high for $\mathrm{Pb}$. Overall, organic phosphorus, nitrate, and lead were revealed to be the most efficient tracers of anthropogenic pollution from local houses and dairy activity. 
Table 2. Results of Mann-Whitney U-test for assessing the difference in element concentration between deep (pristine) and shallow (contaminated) sites. Significant differences at $p<0.05$ are shown by bold numbers. The ratio of median value of the element concentration in shallow (S) and deep (D) site is given by (S)/(D). N.D. stands for non-determined. The elements whose concentration in the deep site exceeds the concentration in shallow site are given in italic.

\begin{tabular}{|c|c|c|c|c|c|c|c|c|c|c|c|c|c|c|}
\hline Date & U-Test & $\mathrm{PO}_{4}{ }^{3-}$ & $\mathbf{P}_{\text {org }}$ & $\mathrm{NO}_{3}{ }^{-}$ & $\mathrm{NH}_{4}{ }^{+}$ & $\mathbf{N}_{\text {org }}$ & Si & Co & $\mathrm{Ni}$ & $\mathrm{Cu}$ & $\mathrm{Zn}$ & As & $\mathrm{Cd}$ & $\mathrm{Pb}$ \\
\hline \multirow{2}{*}{ March 2008} & $p$-value & 1.00 & 0.49 & 0.82 & 0.85 & 0.82 & 0.6 & 0.07 & 0.23 & 0.04 & 0.04 & 0.04 & 0.37 & 1.00 \\
\hline & (S)/(D) & 2.1 & 0.9 & 0.9 & 1.2 & 1.0 & 0.9 & 3.6 & 0.8 & 0.3 & 1.3 & 1.1 & 1.8 & 1.1 \\
\hline \multirow{2}{*}{ July 2008} & $p$-value & 1.00 & 0.01 & 0.01 & 1.00 & 0.04 & 0.46 & N.D. & N.D. & N.D. & N.D. & N.D. & N.D. & N.D. \\
\hline & $(\mathrm{S}) /(\mathrm{D})$ & 0.5 & 1.9 & 0.2 & 1.0 & 1.2 & 0.6 & N.D. & N.D. & N.D. & N.D. & N.D. & N.D. & N.D. \\
\hline \multirow{2}{*}{ March 2009} & $p$-value & 0.01 & 0.04 & 0.01 & 0.52 & 0.92 & 0.52 & N.D. & N.D. & N.D. & N.D. & N.D. & N.D. & N.D. \\
\hline & (S)/(D) & 2.0 & 0.7 & 1.2 & 0.9 & 1.0 & 1.0 & N.D. & N.D. & N.D. & N.D. & N.D. & N.D. & N.D. \\
\hline \multirow{2}{*}{ July 2009} & $p$-value & 0.24 & 0.08 & 0.24 & 0.07 & 0.24 & 0.24 & 1.00 & 0.06 & 0.06 & 0.11 & 0.46 & 0.06 & 0.06 \\
\hline & $(\mathrm{S}) /(\mathrm{D})$ & 0.5 & 6.6 & 0.8 & 0.5 & 1.3 & 0.7 & 1.0 & 0.8 & 1.1 & 0.3 & 1.0 & 0.4 & 2.8 \\
\hline \multirow{2}{*}{ March 2010} & $p$-value & 1.00 & 0.62 & 0.87 & 0.87 & 0.13 & 0.24 & N.D. & N.D. & N.D. & N.D. & N.D. & N.D. & N.D \\
\hline & (S)/(D) & 1.4 & 1.1 & 1.0 & 1.3 & 0.8 & 0.8 & N.D. & N.D. & N.D. & N.D. & N.D. & N.D. & N.D. \\
\hline \multirow{2}{*}{ Auguest 2010} & $p$-value & N.D. & N.D. & N.D. & N.D. & N.D. & N.D. & N.D. & 0.29 & 0.13 & 0.56 & 0.05 & 0.41 & 0.05 \\
\hline & (S)/(D) & N.D. & N.D. & N.D. & N.D. & N.D. & N.D. & N.D. & 0.9 & 1.1 & 1.8 & 1.5 & 1.3 & 12.8 \\
\hline
\end{tabular}




\subsection{Biota of Lake Svyatoe}

The high stability of the hydrochemical parameters of the lake water column is presumably linked to significant internal cycling of carbon-in the organic and inorganic form-between surface and bottom horizons. This is confirmed by a plot of culturable bacterial concentration and the integral values of primary productivity and organic matter mineralization (Figure 4A,B, respectively). In the course of diurnal photosynthesis, the bacterial population of the water column was mostly controlled by $T, \mathrm{pH}, \mathrm{O}_{2}$, and some nutrients, notably phosphate, as shown by correlation coefficients between bacterioplankton parameters and physico-chemical parameters of the surface horizon (Table 3 ). The effect of nitrates and Si on bacterial dynamics was negligible. Parameters of correlations between various groups of bacterioplankton, total bacterial number and biomass of bacterioplankton with $\mathrm{T}$, $\mathrm{pH}$, oxygen, and phosphate are listed in Table 4.

The phytoplankton of lake Svyatoe is typical of other lakes of NW Russia. It is dominated by Cyanophyta, Chrysophyta, Chlorophyta, Bacillariophyta, Dinophyta, and Euglenophyta (Table 5). The ichthyo-fauna of lake Svyatoe is characterized by low biological diversity (eight species), which is common for small northern lakes. All fish belong to four families, and included three freshwater taxons. The core of the ichthyocenosis is composed of two species, the perch and roach. In addition, pike and bream are often present. They are the objects of the local population's fishing. The growth rate of these species generally does not differ from those in other lakes of this climatic zone. However, it should be noted that the population of bream from the lake Svyatoe represents a slow-growing species, some of which are infected with ligula. A similar condition of the bream population was noted for lake Vozhe [24].
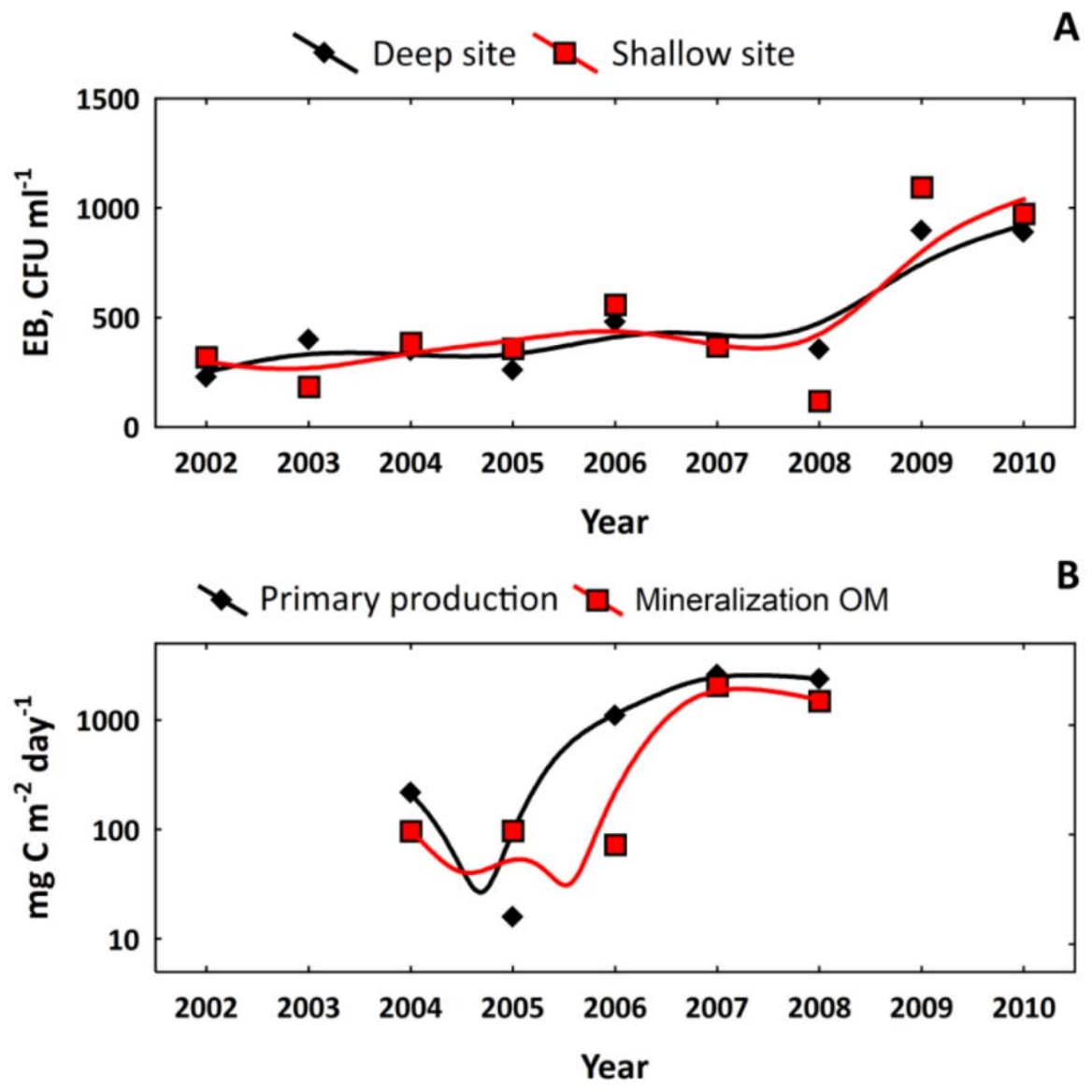

Figure 4. Multi-annual evolution of the concentration of eutrophic bacteria in the epilimnion of deep and shallow stations of (A) the lake; and (B) integral values of all water column primary production and mineralization of organic matter $(\mathrm{OM})$ measured by incubation on the deep site of the lake. 
Table 3. Correlations of bacterioplankton with physico-chemical parameters of the lake water over daily cycle of photosynthesis at the deep station of the lake in the surface horizon. Statistical parameters: $n=20,{ }^{*} p<0.05 ;{ }^{* *} p<0.01$.

\begin{tabular}{cccccccc}
\hline Component of Ecosystem & \multicolumn{7}{c}{$\mathbf{R}^{\mathbf{2}}$} \\
\cline { 2 - 8 } & $\mathbf{T},{ }^{\circ} \mathbf{C}$ & $\mathbf{p H}$ & $\mathbf{T D S}$ & $\mathbf{O}_{2}$ & $\mathbf{N O}_{2}{ }^{-}$ & $\mathbf{P O}_{4}{ }^{3-}$ & $\mathbf{S i}$ \\
\hline Eutrophic bacterioplankton & $0.76^{*}$ & $0.66^{*}$ & -0.43 & $0.75^{*}$ & -0.30 & 0.31 & -0.57 \\
\hline $\begin{array}{c}\text { Facultative-oligotrophic } \\
\text { bacterioplankton }\end{array}$ & 0.15 & 0.11 & 0.41 & $0.74^{*}$ & -0.13 & -0.10 & 0.07 \\
\hline $\begin{array}{c}\text { Total number of } \\
\text { bacterioplankton }\end{array}$ & $0.78^{*}$ & $0.82^{* *}$ & -0.24 & $0.77^{*}$ & 0.32 & $0.60 *$ & -0.40 \\
\hline $\begin{array}{c}\text { Biomass of } \\
\text { bacterioplankton }\end{array}$ & $0.59^{*}$ & $0.66^{*}$ & -0.01 & $0.80 *$ & -0.38 & 0.26 & -0.24 \\
\hline
\end{tabular}

Table 4. Parameters of significant correlations between eutrophic bacterioplankton (EB), facultative-oligotrophic bacterioplankton (FOB), total bacterial number (TB) and biomass of bacterioplankton (BB) with $\mathrm{T}, \mathrm{pH},\left(\mathrm{O}_{2}\right)$, and $\left(\mathrm{PO}_{4}{ }^{3-}\right)$.

\begin{tabular}{ccc}
\hline Temperature & $\mathbf{p H}$ & Oxygen and $\mathbf{P O}_{4}{ }^{3-}$ \\
\hline $\mathrm{EB}=591 \times T-11177$ & $\mathrm{~EB}=1070 \times \mathrm{pH}-7056$ & $\mathrm{~EB}=1492 \times\left(\mathrm{O}_{2}\right)-9731$ \\
- & - & $\mathrm{FOB}=1487 \times\left(\mathrm{O}_{2}\right)-9393$ \\
$\mathrm{~TB}=1.35 \times T-25.4$ & $\mathrm{~TB}=2.97 \times \mathrm{pH}-19.9$ & $\mathrm{~TB}=0.149 \times\left(\mathrm{PO}_{4}{ }^{3-}\right)-0.544$ \\
$\mathrm{BB}=0.586 \times T-11.3$ & $\mathrm{BB}=1.36 \times \mathrm{pH}-9.45$ & $\mathrm{BB}=2.06 \times\left(\mathrm{O}_{2}\right)-14.0$ \\
\hline
\end{tabular}

Table 5. Percentage of various phytoplankton taxa in terms of cell number (N) and biomass (B) at three different horizons of the deepest station of the lake. The dominants are given in bold.

\begin{tabular}{ccccccc}
\hline Parameter & N \% & B \% & N \% & B \% & N \% & B \% \\
\hline Depth & \multicolumn{2}{c}{$\mathbf{0 . 5} \mathbf{~ m}$} & \multicolumn{2}{c}{$\mathbf{5} \mathbf{~ m}$} & \multicolumn{2}{c}{$\mathbf{8 ~ \mathbf { ~ m }}$} \\
\hline Cyanophyta & $\mathbf{8 7 . 2}$ & $\mathbf{2 6 . 5}$ & $\mathbf{8 9 . 8}$ & $\mathbf{5 6 . 0}$ & $\mathbf{7 5 . 6}$ & 4.3 \\
Bacillariophyta & 2.8 & $\mathbf{1 4 . 2}$ & 2.5 & $\mathbf{1 5 . 5}$ & $\mathbf{1 2 . 4}$ & $\mathbf{5 1 . 4}$ \\
Euglenophyta & - & - & 0.0 & 0.3 & - & - \\
Cryptophyta & 2.6 & 3.4 & 3.4 & 4.9 & 2.8 & 2.1 \\
Dinophyta & 0.2 & $\mathbf{4 9 . 7}$ & 0.1 & $\mathbf{2 1 . 0}$ & 0.3 & $\mathbf{3 9 . 4}$ \\
Chrysophyta & - & - & 0.1 & 0.6 & - & - \\
Chlorophyta & 6.4 & 3.9 & 2.9 & 1.3 & 4.4 & 1.4 \\
Xanthophyta & - & - & - & - & - & - \\
Flagellata & 0.7 & 0.3 & 1.1 & 0.4 & 4.6 & 1.4 \\
Raphidophyta & - & - & - & - & - & - \\
\hline
\end{tabular}

\subsection{Carbon Biogeochemistry}

The greatest stability of the lake ecosystem to external factors is known to occur at high fluxes of carbon between various reservoirs, accompanied by high rates of primary production of phytoplankton and mineralization of dissolved and particulate organic matter via heterotrophic bacterial component. This is a common feature of the stability of a complex self-organized system. Therefore, the most adequate indicators of the change in ecosystem stability are the parameters of the biogeochemical cycle of carbon.

The relationship between DOC and DIC is one of the key parameters defining the overall stability of the lake ecosystem and its auto-purification potential. This ratio is shown in Figure 5, which demonstrates a systematic decrease of this value from the surface to the deeper horizons, thus illustrating significant mineralization of dissolved organic matter in the hypolimnion. This is especially pronounced during winter, under the ice coverage. Consistent with this, an integral value of organic 
matter mineralization exceeds that of the primary production in the water column of the lake (Figure 6), strongly suggesting net heterotrophic status of Svyatoe, similar to many other humic lakes of the boreal zone $[1,25,26]$. Note the quite low primary productivity and mineralization of organic matter in March and elevated, but highly variable, values of the intensity of both processes during summer.

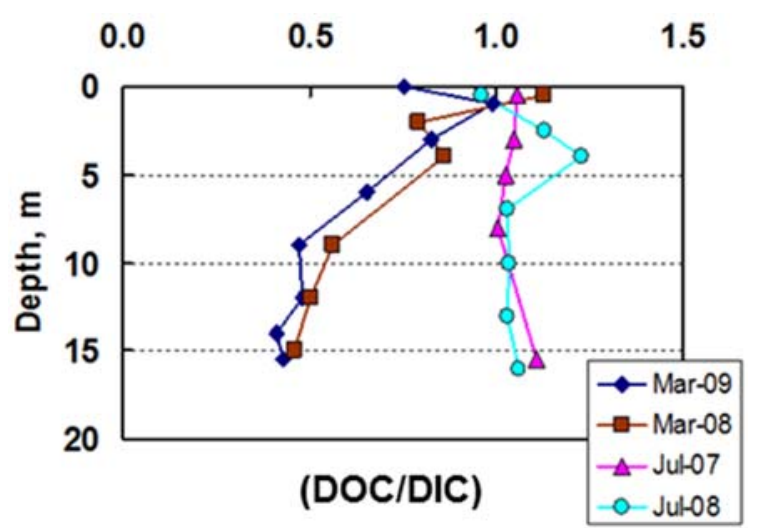

Figure 5. The ratio of dissolved organic (DOC) to dissolved inorganic carbon (DIC) in Svyatoe during March and July.
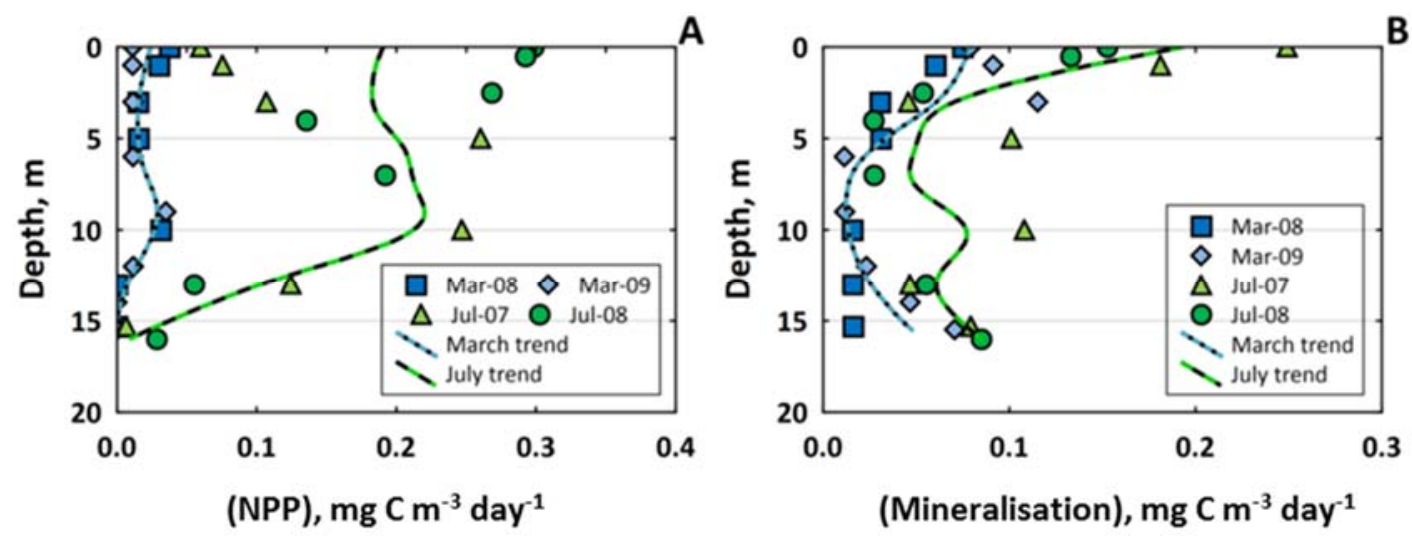

Figure 6. Depth-resolved values of (A) primary productivity; and (B) total mineralization in the water column of Lake Svyatoe. The integral value of net primary production (NPP) exceeds that of mineralization by $30 \%$ to $50 \%$ suggesting possible net emission of $\mathrm{CO}_{2}$ to the atmosphere over the full period of observation.

\subsection{Trace Metal Speciation and Cycling in the Water Column}

Analysis of trace element behavior in the water column and their colloidal speciation via dialysis allowed better understanding of processes controlling trace metal cycling in the lake. Fe is the main constituent of the dissolved $(<0.45 \mu \mathrm{m})$ metal pool, ranging in concentration from $80 \pm 30 \mu \mathrm{g} \cdot \mathrm{L}^{-1}$ at the surface to $150 \pm 50 \mu \mathrm{g} \cdot \mathrm{L}^{-1}$ in the hypolimnion over 7 years of observation (Figure 7 ). Such a high concentration of $\mathrm{Fe}$ in the lake water is most likely linked to its colloidal status in the form of organo-mineral colloids ( $1 \mathrm{kDa}-0.45 \mu \mathrm{m}$, ref. [27]). We could not detect any link $(p>0.05)$ between Fe concentration and the degree of stratification in the water column with water temperature, precipitation, or any other major environmental parameter. 


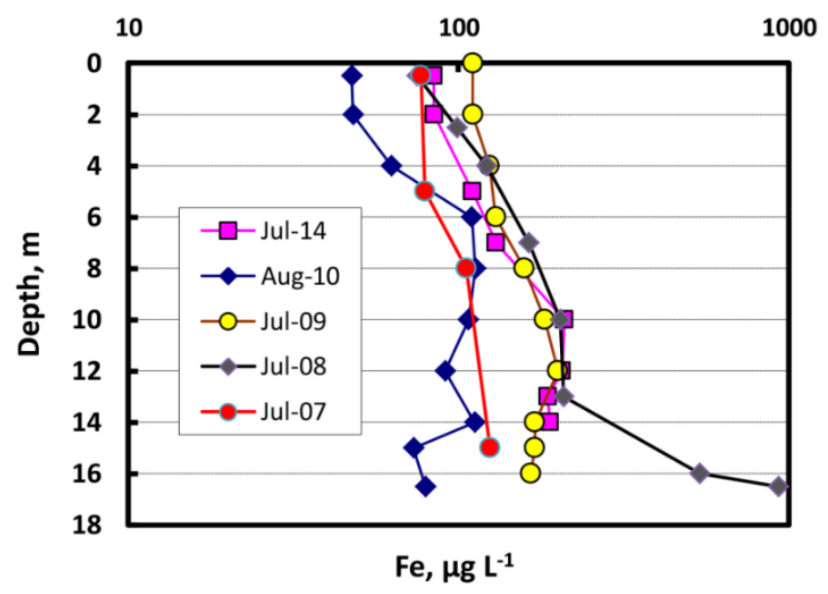

Figure 7. Fe concentration in the water column of the deep station over past 7 years.

During all seasons, large colloidal forms $(0.025-0.45 \mu \mathrm{m})$ of iron and insoluble trivalent and tetravalent elements dominated the size fractionation of dissolved elements. The change in speciation of trace elements (TEs) with depth was due to (i) redox condition changes; (ii) the biodegradation of sinking plankton biomass that released dissolved organic matter over the entire water column; and (iii) the diffuse flux from the sediments to the water column in the hypolimnion (Figure 8). Thus, $\mathrm{Fe}^{2+}$ appearance at the chemocline during winter stagnation leads to a significant decrease and almost to the disappearance of colloidal forms at the lake bottom similar to other boreal seasonally-stratified lakes [12]. An influx of Fe(II) from the sediments is supported by the concave shape of the Fe profiles, which points towards diffusive processes from the sediment rather than production processes within the water column. This result is in agreement with the large body of evidence from temperate lakes, showing that the seasonal increase in iron in the anoxic bottom waters is largely due to a release from the sediment [28]. In addition to low molecular weight (LMW, $<1 \mathrm{kDa}$ ) phytoplankton exometabolites, important process responsible for the production of LMW organic ligands in the surface layers may be the photooxidation of DOM (e.g., refs. [29-31]). In a humic boreal lake, photooxidation is responsible for at least $10 \%$ of total OM degradation [32], although the relative importance of this process for the production of LMW complexes of DOC and TEs in Lake Svyatoe cannot be evaluated.

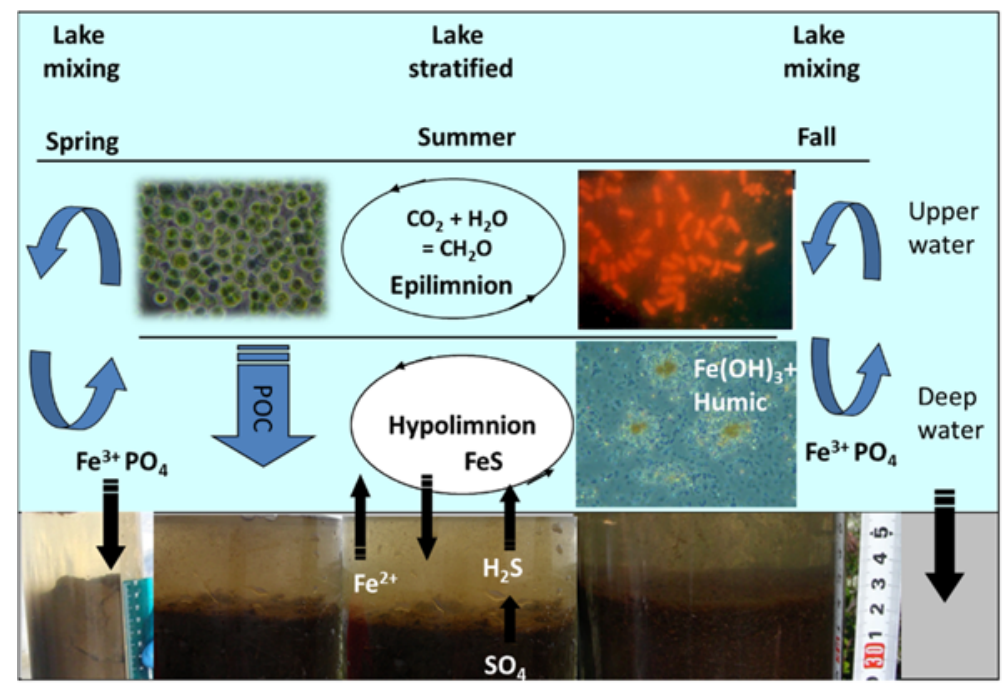

Figure 8. A cartoon of DOC, Fe, and related element cycling in seasonally-stratified Lake Svyatoe studied in this work. Coupled transport, biodegradation, and sedimentation of Fe-rich colloids and many trace elements is a specific feature of this humic, Fe-rich lake of NW Russia. 
The photoreduction of $\mathrm{Fe}^{3+}$ in the surface layers may additionally be an important phenomena, especially in the spring and early summer after the lake overturn brings high concentrations of colloidal Fe(III) from the bottom horizons (i.e., Figure 7) to the upper five to seven surface layers. In contrast, in summertime, the photoreaction of Fe(III) under the visible range of light and UV may produce labile ( $<100 \mathrm{Da}) \mathrm{Fe}$, as shown in experiments on boreal stream waters [33]. The poorly understood process that is responsible for colloidal metal production in the hypolimnion involves iron sulfide formation in the anoxic zone of sediment porewater and the adjacent water column [28]. These FeS nanoparticles are capable of scavenging some trace metals [34,35]. Given elevated sulfide concentrations in the hypolimnion of Lake Svyatoe (from $0.24 \mu \mathrm{M}$ at the surface to $1.18 \mu \mathrm{M}$ at the bottom [36]), colloidal iron sulfide may be potentially important and deserves special investigation using size fractionation techniques.

To resume, the colloid origin and migration in Lake Svyatoe are chiefly affected by the biogeochemical cycle of carbon and iron. The governing factors of colloid origin and transformation include the following: (1) biological processes of phytoplankton production and heterotrophic bacterioplankton mineralization in the water column during summer and winter stagnation, which leads to the appearence of organic LMW colloids similar to other boreal [37] and thermokarst [16] lakes; (2) the input of allochthonous soil and bog OM in the form of high molecular weight (HMW) organo-mineral colloids, which is typical for the boreal zone of NW Russia [38,39]; and (3) the diffuse flux of $\mathrm{Fe}^{2+}$, other trace metals, and DOM from the sediment porewater to the bottom horizons [40].

Rapid oxygenation of deep water layers during the spring and autumn overturn, and the input of large soil and bog water organo-ferric colloids causes changes in both element concentrations and their colloidal status. The relative proportion of these colloidal pools varies as a function of depth and season. It is therefore possible that organo-ferric colloids that control the speciation of poorly-soluble elements in soil and river waters are being replaced by autochthonous organic colloids in the lake system. However, the bio-availability of these Fe-rich colloids to most aerobic and anaerobic bacterioplankton remains virtually unknown, and special incubation experiments are necessary to reveal the coupling between organic carbon, metals, and bacterial activity (i.e., ref. [41]). Finally, seasonal evolution of phytoplankton population and the influence of the lake's hydrochemistry on phytoplankton biomass and cell number-similar to that revealed in other shallow boreal lakes (i.e., ref. [42])—should be also assessed. The evolution of these relationships in response to the change of water temperature or the increase of the input of anthropogenically-related nutrients remains the subject of future research.

\section{Conclusions}

For ten years, we have been studying the hydrochemistry and trophic status of Lake Svyatoe, a heterogeneous seasonally stratified lake with varying degrees of human impact on different parts of this area. Assessment of the environmental status of Lake Svyatoe is particularly relevant at present, because it can serve as a model of water bodies used by the local population for economic, household, and recreational purposes, while being isolated from intensive anthropogenic and industrial influence. Such rural facilities dominate in the Nordic countries and in Western Europe and will inevitably become a point of "attraction" of population growth, provided adequate infrastructure development of the road network in the northwest region of Russia. In the course of many years of complex work, the results obtained on hydrological and hydro-chemical, hydro-biological and ichthyological studies of the lake allow us to describe the current state and functioning of aquatic communities, and to evaluate the self-purification potential of the ecosystem. The distribution tendencies of ecosystem components at different time scales allowed us to assess the daily dynamics and seasonal and interannual variabilities. Based on a comprehensive analysis of the ecological status of the lake, we performed field experiments to assess the potentially "bioavailable" DOC and to model microbial degradation of autochthonous and allochthonous DOC.

Measurements of the relative proportion of colloids as a function of depth during different seasons allowed for an assessment of the autochthonous and allochthonous pools of colloidal material as 
a function of the (1) biological processes of phytoplankton production leading to the presence of mainly organic low molecular weight colloids; (2) input of allochthonous soil and bog OM present in the form of high molecular weight organo-mineral colloids; and (3) diffuse flux of Fe(II), certain trace metals, and organic matter from the sediment porewater to the bottom horizons. Results of the present work allow the identification of the redox processes in the hypolimnion and the organic detritus degradation leading to the chemical stratification in small boreal lakes. Assessing these processes over several years of observation provided the necessary database for subsequent quantitative modeling.

The ratio of the contribution of organic and inorganic components to the overall carbon balance depends on the season, as follows from the measurements of intensity of primary production-heterotrophic mineralization processes. Over more than a decade of monitoring of the lake ecosystem in the summer period, we demonstrate that the trophic status of the water body, the gas exchange with the atmosphere, and the exchange of dissolved components with the sediments are largely determined by the concentration of autochthonous and allochthonous DOC.

Acknowledgments: This work was supported by the RFBR (grants 14-05-98815 r_sever_a, 14-05-31533 mol_a, and 15-05-05000), FASE Russia under the theme No. 0410-2014-0030, RSF grant No. 15-17-10009 and BIO-GEO-CLIM grant No. 14.B25.31.0001.

Author Contributions: L.S., T.V., S.Z. and O.P. conceived and designed the sampling and experiments; S.K., O.M. and A.C. performed hydrological and hydrochemical study and wrote Section 3.1; T.V., O.M. and A.E. analyzed nutrient behavior and wrote Section 3.2; N.M., V.G. and E.S. performed the sampling and analysis of hydrobiology and wrote Section 3.3; L.S., S.Z., N.K. analyzed behavior of carbon and wrote Section 3.4; A.C., N.S. and O.P. performed sampling and analysis of trace elements and wrote Section 3.5. All authors equally contributed to Sections 1, 2 and 4 .

Conflicts of Interest: The authors declare no conflict of interest.

\section{References}

1. Algesten, G.; Sobek, S.; Bergstro, A.K.; Agren, A.; Tranvik, L.J.; Jansson, M. Role of lakes for organic carbon cycling in the boreal zone. Glob. Chang. Biol. 2003, 10, 141-147. [CrossRef]

2. Worrall, F.; Harriman, R.; Evans, C.D.; Watts, C.D.; Adamson, J.; Neal, C.; Tipping, E.; Burt, T.; Grieve, I.; Monteith, D.; et al. Trends in dissolved organic carbon in UK rivers and lakes. Biogeochemistry 2004, 70, 369-402. [CrossRef]

3. Kothawala, D.N.; Stedmon, C.A.; Müller, R.A.; Weyhenmeyer, G.A.; Köhler, S.J.; Tranvik, L.J. Controls of dissolwed organic matter quality: Evidence from a large-scale boreal lake suvery. Glob. Chang. Biol. 2014, 20, 1101-1114. [CrossRef] [PubMed]

4. Pagano, T.; Bida, M.; Kenny, J.F. Trends in levels of allochthonous dissolved organic carbon in natural water: A review of potential mechanisms under a changing climate. Water 2014, 6, 2862-2897. [CrossRef]

5. Grönlund, E. The recovery of two polluted subarctic lakes-towards nutrient management or a pristine state? Water 2012, 4, 793-814. [CrossRef]

6. Filella, M.; Rodrigues-Murillo, J.C. Long-term trends of organic carbon concentrations in freshwaters: Strengths and weaknesses of existing evidence. Water 2014, 6, 1360-1418. [CrossRef]

7. Kvasov, D.D.; Martinson, G.G.; Raykas, A.V. History of Lake Ladoga, Lake Onega, Pskovsko-Chudskoe Lakes, Lake Baikal and Lake Hankey; Nauka: Leningrad, Russia, 1990. (In Russian)

8. Sayad, L.; Kherici-Bousnoubra, H.; Drouiche, N.; Houhamdi, M.; Kherici, N. Calculation and interpretation of effluent discharge objectives of dairy industry: Case Edough's dairy-Annaba (Algeria). Ecol. Eng. 2014, 73, 421-424. [CrossRef]

9. Bahroun, S.; Bousnoubra, H.; Drouiche, N.; Kherici, N. Analysis of wastewater discharges to the Wadi Kebir East River by the environmental discharge objectives (EDO) method. Desal. Water Treat. 2016. [CrossRef]

10. Shirokova, L.S.; Pokrovsky, O.S.; Moreva, O.Y.; Chupakov, A.V.; Zabelina, S.A.; Klimov, S.I.; Shorina, N.V.; Vorobieva, T.Y. Decrease of concentration and colloidal fraction of organic carbon and trace elements in response to the anomalously hot summer 2010 in a humic boreal lake. Sci. Total Environ. 2013, 463/464, 78-90. [CrossRef] [PubMed]

11. Pokrovsky, O.S.; Shirokova, L.S. Diurnal variations of dissolved and colloidal organic carbon and trace metals in a boreal lake during summer bloom. Water Res. 2013, 47, 922-932. [CrossRef] [PubMed] 
12. Pokrovsky, O.S.; Shirokova, L.S.; Zabelina, S.A.; Vorobieva, T.Y.; Moreva, O.Y.; Klimov, S.I.; Chupakov, A.V.; Shorina, N.V.; Kokryatskaya, N.M.; Audry, S.; et al. Size fractionation of trace elements in a seasonally stratified boreal lakes: Control of organic matter and iron colloids. Aquat. Geochem. 2012, 18, 115-139. [CrossRef]

13. Koroleff, F. Total and organic nitrogen. In Methods for Seawater Analysis; Grasshoff, K., Ehrhardt, M., Kremling, K., Eds.; Verlag Chemie: Weinheim, Germany, 1983; pp. 162-168.

14. Koroleff, F. Determination of phosphorus. In Methods for Seawater Analysis; Grasshoff, K., Ehrhardt, M., Kremling, K., Eds.; Verlag Chemie: Weinheim, Germany, 1983; pp. 125-136.

15. Shirokova, L.S.; Pokrovsky, O.S.; Kirpotin, S.N.; Dupré, B. Heterotrophic bacterio-plankton in thawed lakes of northern part of Western Siberia controls the $\mathrm{CO}_{2}$ flux to the atmosphere. Int. J. Environ. Stud. 2009, 66, 433-445. [CrossRef]

16. Shirokova, L.S.; Pokrovsky, O.S.; Kirpotin, S.N.; Desmukh, C.; Pokrovsky, B.G.; Audry, S.; Viers, J. Biogeochemistry of organic carbon, $\mathrm{CO}_{2}, \mathrm{CH}_{4}$, and trace elements in thermokarst water bodies in discontinuous permafrost zones of Western Siberia. Biogeochemistry 1983, 113, 573-593. [CrossRef]

17. Shirokova, L.S.; Pokrovsky, O.S.; Viers, J.; Klimov, S.I.; Moreva, O.Y.; Zabelina, S.A.; Vorobieva, T.Y.; Dupré, B. Diurnal variations of trace elements and heterotrophic bacterioplankton concentration in a small boreal lake of the White Sea basin. Ann. Limnol. 2010, 46, 67-75. [CrossRef]

18. Guseva, K.A. Methods of phytoplankton counting. Trudy Inst. Biol. Vodochr. 1959, 2, 44-51. (In Russian)

19. Trifonova, I.S. Phytoplankton composition and biomass structure in relation to trophic gradient in some temperate and subarctic lakes of northwestern Russia and the Prebaltic. Hydrobiologia 1998, 369/370, 99-108. [CrossRef]

20. Makarova, I.V.; Pichkily, L.O. On some questions of the method of biomass of phytoplankton calculation. Bot. J. (Botanicheskii Zhurnal) 1970, 55, 1488-1494.

21. Odum, E.P. Fundamentals of Ecology; Saunders: Philadelphia, PA, USA, 1971.

22. Sladecek, V. System of water quality from the biological point of view. Arch. Hydrobiol. 1973, 7, 1-218.

23. Barinova, S.S.; Medvedeva, L.A.; Anisimova, O.V. Biodiversity of Algae-Indicators of the Environment; Tell-Aviv Publ. House: Tel-Aviv, Israel, 2006.

24. Zhakov, L.A. Formation and Stricture of Fish Population of Lakes of NW of the USSR; Nauka: Moscow, Russia, 1984. (In Russian)

25. Sobek, S.; Algesten, G.; Bergstrom, A.K.; Jansson, M.; Tranvik, L.J. The catchment and climate regulation of $\mathrm{pCO}_{2}$ in boreal lakes. Glob. Chang. Biol. 2003, 9, 630-641. [CrossRef]

26. Sobek, S.; Söderbäck, B.; Karsson, S.; Andersson, E.; Brunbergn, A.-K. A carbon budget of a small humic lake: An example of the importance of lakes for organic matter cycling in boreal catchments. Ambio 2006, 35, 469-475. [CrossRef]

27. Pokrovsky, O.S.; Viers, J.; Dupré, B.; Chabaux, F.; Gaillardet, J.; Audry, S.; Prokushkin, A.S.; Shirokova, L.S.; Kirpotin, S.N.; Lapitsky, S.A.; et al. Biogeochemistry of carbon, major and trace elements in watersheds of Northern Eurasia drained to the Arctic Ocean: The change of fluxes, sources and mechanisms under the climate warming prospective. C. R. Geosci. 2012, 344, 663-677. [CrossRef]

28. Hamilton-Taylor, J.; Smith, E.J.; Davison, W.; Sugiyama, M. Resolving and modeling the effects of Fe and Mn redox cycling on trace metal behavior in a seasonally anoxic lake. Geochim. Cosmochim. Acta 2005, 69, 1947-1960. [CrossRef]

29. Amon, R.M.W.; Benner, R. Photochemical and microbial consumption of dissolved organic carbon and dissolved oxygen in the Amazon River System. Geochim. Cosmochim. Acta 1996, 60, 1783-1792. [CrossRef]

30. Jonsson, A.; Aberg, J.; Lindroth, A.; Jansson, M. Gas transfer rate and $\mathrm{CO}_{2}$ flux between an unproductive lake and the atmosphere in northern Sweden. J. Geophys. Res. 2008, 113, G04006. [CrossRef]

31. Jonsson, A.; Meili, M.; Bergstrom, A.K.; Jansson, M. Whole-lake mineralization of allochthonous organic carbon in a large humic lake (Ortrasket, N. Sweden). Limnol. Oceanogr. 2001, 46, 1691-1700. [CrossRef]

32. Pers, C.; Rahm, L.; Jonsson, A.; Bergström, A.K.; Jansson, M. Modelling dissolved organic carbon turnover in humic Lake Örträsket, Sweden. Environ. Model. Assess. 2001, 6, 159-172. [CrossRef]

33. Kelton, N.; Molot, L.A.; Dillon, P.J. Effect of ultraviolet and visible radiation on iron lability in boreal and artificial waters. Aquat. Sci. 2007, 69, 86-95. [CrossRef]

34. Balistrieri, L.S.; Murray, J.W.; Paul, B. The geochemical cycling of trace elements in a biogenic meromictic lake. Geochim. Cosmochim. Acta 1994, 58, 3993-4008. [CrossRef] 
35. Balistrieri, L.S.; Murray, J.W.; Paul, B. The geochemical cycling of stable $\mathrm{Pb},{ }^{210} \mathrm{~Pb}$, and ${ }^{210} \mathrm{Po}$ in seasonally anoxic Lake Sammamish, Washington, USA. Geochim. Cosmochim. Acta 1995, 59, 4845-4861. [CrossRef]

36. Kokryatskaya, N.M.; Zabelina, S.A.; Savvichev, A.S.; Moreva, O.Y.; Vorovieva, T.Y. Seasonal Biogeochemical and Microbiological Studies of Small Lakes in Taiga Zone of Northwestern Russian (Arkhangelsk Province). Water Resour. 2012, 39, 105-117. [CrossRef]

37. Tranvik, L.J.; Downing, J.A.; Cotner, J.B.; Loiselle, S.A.; Striegl, R.G.; Ballatore, T.J.; Dillon, P.; Finlay, K.; Fortino, K.; Knoll, L.B.; et al. Lakes and reservoirs as regulators of carbon cycling and climate. Limnol. Oceanogr. 2009, 54, 2298-2314. [CrossRef]

38. Pokrovsky, O.S.; Schott, J. Iron colloids/organic matter associated transport of major and trace elements in small boreal rivers and their estuaries (NW Russia). Chem. Geol. 2002, 190, 141-179. [CrossRef]

39. Vasyukova, E.V.; Pokrovsky, O.S.; Viers, J.; Oliva, P.; Dupré, B.; Martin, F.; Candaudaup, F. Trace elements in organic- and iron-rich surficial fluids of the Boreal zone Assessing colloidal forms via dialysis and ultrafiltration. Geochim. Cosmochim. Acta 2010, 74, 449-468. [CrossRef]

40. Audry, S.; Pokrovsky, O.S.; Shirokova, L.S.; Kirpotin, S.N.; Dupré, B. Organic matter mineralization and trace element post-depositional redistribution in Western Siberia thermokarst lake sediments. Biogeosciences 2011, 8, 565-583. [CrossRef]

41. Shirokova, L.S.; Bredoire, R.; Rols, J.-L.; Pokrovsky, O.S. Moss and peat leachate degradability by heterotrophic bacteria: Fate of organic carbon and trace metals. Geomicrobiol. J. 2015. [CrossRef]

42. Pavlova, O.A.; Pokrovsky, O.S.; Manasypov, R.M.; Shirokova, L.S.; Vorobyev, S.N. Seasonal dynamics of phytoplankton in acidic and humic environment in shallow thaw ponds of western Siberia, discontinuous permafrost zone. Ann. Limnol. 2016, 52, 47-60. [CrossRef]

(C) 2016 by the authors; licensee MDPI, Basel, Switzerland. This article is an open access article distributed under the terms and conditions of the Creative Commons Attribution (CC-BY) license (http:/ / creativecommons.org/licenses/by/4.0/). 